Cuadernos de Historia Moderna

ISSN-e 1988-2475

http://dx.doi.org/10.5209/CHMO.60667

\title{
¿Por qué la Leyenda Negra? ¿Por qué ahora?
}

[en] Why The Black Legend? Why now?

Yolanda Rodríguez Pérez, Antonio Sánchez Jiménez y Harm Den Boer (eds.), España ante sus críticos: las claves de la Leyenda Negra, Madrid-Frankfurt am Main, Iberoamericana-Vervuert, 2015.

María Elvira Roca Barea, Imperiofobia y leyenda negra: Roma, Rusia, Estados Unidos y el Imperio español, Madrid, Siruela, 2016.

María José Villaverde Rico y Francisco Castilla Urbano (dirs.), La sombra de la leyenda negra, Madrid, Tecnos, 2016.

Ricardo García Cárcel, El demonio del Sur. La Leyenda Negra de Felipe II, Madrid, Cátedra, 2017).

Al inicio de El demonio del Sur, su magistral relato del proceso de denigración al que fue sometido Felipe II a lo largo de la Edad Moderna, Ricardo García Cárcel señala: "Es sorprendente que tanta pasión esté generando un tema [la leyenda negra] que parecía enterrado" (p. 25). Es la misma pregunta que yo me he hecho en muchas ocasiones mientras me ocupaba de escribir esta reseña.

En las décadas de 1960 y 1970, cuando empecé a estudiar y a escribir sobre la historia de España, mis colegas estadounidenses, teniendo presentes, sin duda, el régimen de Franco, la Inquisición, la devastación de las culturas indígenas del Nuevo Mundo y aún más la reputación de España como un país de escaso protagonismo en el avance de la civilización occidental, con frecuencia me preguntaban: ¿por qué España? Mis respuestas variaban. En alguna ocasión, invoqué mi fascinación por los singulares retos a los que España, como sociedad multiétnica durante buena parte de su historia, había tenido que hacer frente. En cuanto a la Inquisición, aunque nunca disculpé sus excesos, recalcaba la importancia y las posibilidades que estaban esperando a los investigadores en los archivos inquisitoriales tanto de Cuenca como de Madrid. A propósito de las Indias, mi respuesta, por lo general, aludía a los desafíos particulares que aguardaban a los aventureros que se toparon con un Nuevo Mundo y encontraron pueblos cuyas costumbres les resultaban extrañas y, en ocasiones, aterradoras.

En años más recientes, la pregunta “¿por qué España?” me la hacen ya con mucha menos frecuencia. Por el contrario, los colegas parecen más dispuestos a destacar lo afortunado que he sido por haber elegido España como campo de estudio, a la luz de la riqueza y complejidad de su cultura y de que, junto a Portugal, sirvió como espacio de pruebas de muchos problemas a los que se enfrenta el actual mundo globalizado. 
En otras palabras, si la España de mi juventud era mirada como un paria, hoy en día esa España -la España de la Leyenda Negra- ha desaparecido casi del todo.

A la luz de tales cambios, estoy perplejo ante el reciente resurgir en la España actual del interés por la Leyenda Negra. En los Estados Unidos, el último libro de importancia dedicado a la materia era Rereading the Black Legend: The Discourse of Religious and Racial Difference in the Renaissance Empires (University of Chicago Press, 2007), un volumen explícitamente revisionista que examinaba las dificultades a las que varios imperios modernos, entre ellos España, hicieron frente al ocuparse de cuestiones relativas a la diferencia racial y religiosa. Más recientemente, algunos historiadores interesados por las actitudes norteamericanas hacia España en los Estados Unidos han empezado a desplazar su enfoque desde los característicos temas de la Leyenda Negra hacia la visión más positiva del país surgida en las décadas inmediatamente posteriores a la guerra del 98. Los estudios incluidos en When Spain Fascinated America (Fundación Zuloaga, 2010) anunciaron este cambio de dirección, aunque ninguno de ellos ha sido citado en los volúmenes que ahora reseñamos. Así es que la cuestión sigue abierta: ¿qué explica la atención que la Leyenda Negra recibe en la España de hoy? ${ }^{1}$

Como posible respuesta, Roca Barea sugiere que podría ser una reacción a la crítica europea -léase alemana- a los hábitos "despilfarradores" del país surgida durante la reciente crisis financiera española. Por el contrario, M. J. Villaverde Rico y F. Castilla Urbano sugieren que sus raíces son internas y están ligadas a debates políticos sobre el estatus de la nación española que todavía están abiertos. Su punto de partida es $L a$ Leyenda Negra. Una polémica nacionalista en la España del siglo XX (Catarata, 2011) de Jesús Villanueva. Este perspicaz volumen mostraba cómo Primo de Rivera, Franco y otros defensores de una "España unida" a lo largo del siglo XX se sirvieron de la Leyenda Negra para aglutinar el apoyo interno a su particular marca de política nacionalista. Continúa sugiriendo que cuando el Partido Popular llegó al poder, en 1996, sus líderes mantuvieron un discurso similar. Villanueva resume este proceso en esta concisa sentencia: "[Julián] Juderías -el escritor nacionalista de comienzos del siglo XX que popularizó la noción de Leyenda Negra- ha vuelto."

Sea cual sea la causa precisa de la vigente oleada de interés por la Leyenda Negra, la materia obviamente fascina a los lectores españoles, como demuestra el imparable éxito editorial de Imperiofobia y leyenda negra de Roca Barea. Este volumen irregular, aunque bastante legible, argumenta que los imperios, por su misma naturaleza, generan críticas. Empezando por Roma y continuando por los imperios de Rusia, Gran Bretaña y Estados Unidos, demuestra que los defectos atribuidos a las autoridades imperiales - codicia, crueldad bárbara, falta de cultura, etc.- son más o menos los mismos y sintetiza esta idea en la observación de que Leyendas Negras e imperios forman "una pareja inseparable." Desde su punto de vista, por tanto, era inevitable que el imperio sobre el que no se ponía el Sol originase varias madejas de hispanofobia. Tejidas juntas, constituyeron la Leyenda Negra sobre la que más tarde escribiría Juderías.

Entre otros libros recientes que también se ocupan de la Leyenda Negra se encuentran Antonio Cortijo Ocaña, Herejia, Inquisición y Leyenda Negra en el Siglo XVII, Madrid, Calambur, 2016; Iván Vélez Cipriano, Sobre la leyenda negra, $2^{\mathrm{a}}$ ed. corregida, Madrid, Encuentro, 2018; y una nueva edición de Sverker Arnoldsson, Los orígenes de la Leyenda Negra Española, Sevilla, El Paseo Editorial, 2018, originalmente publicada en 1960 . 
La presentación de Roca Barea de esta leyenda se mueve en el territorio habitual -crítica anglo-holandesa a Felipe II, uso generalizado de Las Casas como testigo privilegiado de las atrocidades españolas en América y, a partir de finales del siglo XVII, crítica de la Inquisición y de su papel a la hora de sofocar la vida intelectual española. Al mismo tiempo, recurre a la "leyenda blanca" para subrayar las contribuciones de España a la civilización en América y también para sugerir que independientemente de cuales fueran los errores cometidos por España en el trato de los pueblos indígenas, los perpetrados por Gran Bretaña y los Estados Unidos no fueron menos y posiblemente peores. Esta apasionada defensa del papel de España como actor histórico cae en excesos, pero también ayuda a explicar por qué este libro rápidamente se ha convertido en un éxito de ventas.

Pese a su atractivo, la afirmación de Roca Barea de que imperios y Leyendas Negras constituyen una pareja inseparable no explica la persistencia de la hispanofobia en el siglo siguiente a que España perdiese su imperio en 1898. Su respuesta a este enigma es completamente insatisfactoria. Para empezar, no hace referencia a Franco ni a cómo su oposición a la democracia y su régimen de férrea censura insuflaron vida nueva al repertorio de viejos estereotipos que databan de tiempos de Felipe II. En el caso de la hispanofobia del período posterior al franquismo, Roca Barea exagera su importancia, junto a lo que ve como acendrados prejuicios anticatólicos en la Europa y la Norteamérica protestantes. Mientras que esos prejuicios sí influyeron a escritores del XVI como John Foxe, a muchos viajeros británicos en la España del XVIII, así como a Henry C. Lea y a otros historiadores decimonónicos, guardan escasa relación con su presentación de por qué España, junto a Grecia, Italia y Portugal, han sido etiquetados como despilfarradores durante la reciente crisis financiera.

Ni tampoco estos prejuicios necesariamente pueden emplearse en el retrato de Felipe II como "el demonio del sur" hecho por Voltaire. Como García Cárcel explica, la reputación de este monarca como un agente maléfico no puede ser atribuida sólo a los protestantes, ni tampoco a la religión. Siguiendo argumentos ya presentados en publicaciones anteriores, reitera su afirmación de que las críticas contemporáneas a Felipe II -el protagonista estelar de la Leyenda Negra- eran esencialmente un resultado adverso de sus políticas agresivas - "imprudentes" según Geoffrey Parkertanto internas como exteriores. De lo contrario, sería imposible explicar las muchas críticas que el rey recibió de sus contemporáneos católicos -en Roma y en Venecia, en Lisboa, en París, donde Brantôme compuso su venenoso relato de la muerte de Don Carlos; en Zaragoza, donde los súbditos aragoneses del monarca se rebelaron para protestar contra lo que percibían como la supresión de sus libertades tradicionales por orden real; por no hablar de Madrid, donde los profetas Miguel de Piedrola y Lucrecia de León atacaron abiertamente tanto la persona como las políticas del rey.

Es probable que los historiadores interesados en Felipe II conozcan ya la mayor parte de estas críticas y a este respecto El demonio del Sur cambia, o amplia, poco la comprensión del canon de literatura antifilipina ya establecido. Su valor radica más bien en el certero análisis de García Cárcel de las fuentes que contribuyeron al vilipendio de Felipe durante el siglo XVI, así como en su magistral presentación de cómo los historiadores de siglos posteriores usaron esas fuentes para crear su propia, abrumadoramente negativa, imagen del rey. A la importancia del volumen se suma el apéndice que incluye un compendio de extractos -traducidos al español- de algunas de estas fuentes, incluidas partes fundamentales de Fuora villaco de José Teixeira y de las memorias de Brantôme. 
No es de extrañar que muchas de estas fuentes figuren igualmente en los trabajos reunidos en España ante sus críticos, aunque este volumen recurre también a otras que eran desconocidos hasta ahora, poco utilizados o ambas cosas. Se propone corregir la noción de que los españoles no lograron responder a las críticas que se les hacían. Este toma y daca es especialmente evidente en el ensayo de Fernando Bouza sobre la defensa de los derechos de Felipe II a Portugal hecha por Duarte Nunes de Leão, el análisis de Yolanda Rodríguez Pérez de la respuesta de Pedro Cornejo a la Apologie dimafatoria de Guillermo de Orange de 1581, así como en las reflexiones de Alexander Samson sobre la oposición inglesa a Felipe II durante el reinado de María Tudor. También es central en el trabajo de Carmen Sanz Ayán sobre Génova. En una primera parte, se examinan las críticas genovesas a las "ambizione e cupidigia [codicia]" españolas, junto a otras que sugerían que la antigua alianza con España había sido "fatal a nuestra República", mientras que en la segunda parte se examinan las respuestas a estas críticas durante el período de Felipe IV. Y mientras en la discusión de Martínez Luna sobre la obra de Tommaso Campanella aparecen dos imágenes de España - una positiva, negativa la otra-, no figuran éstas en la presentación de López Moreda de los orígenes italianizantes del tópico "Non Placet Hispania", el análisis de Eric Griffin de los conceptos y personajes hispanófobos que aparecen en la escena inglesa de las décadas siguientes a la derrota de la Armada ni tampoco en el ensayo de Harm den Boer sobre la imagen de España en la obra de Francisco de Cáceres y otros "expatriados" que vivían en los Países Bajos.

Si España ante sus críticos tiene como objetivo principal estudiar las respuestas españolas a las críticas durante los siglos XVI y XVII, La sombra de la Leyenda Negra es mucho más amplia, ofreciendo lo que sus editores describen como "un análisis de los orígenes y persistencia de la leyenda negra y una reflexión sobre su impacto y las reacciones que provoca". Ese análisis se abre con un "estudio preliminar" de 98 páginas que presenta el estado de la cuestión y contiene quince ensayos que cubren cronológicamente desde el siglo XVI hasta finales del XIX. La mayoría de ellos se mueven por territorio conocido, siendo el punto de partida la Brevísima de Las Casas y las diferentes maneras en las que autores holandeses en los Países Bajos y predicadores en Nueva Inglaterra recurrieron a ella con vistas a lograr los objetivos propagandísticos holandeses. La crítica ilustrada a España viene a continuación. Aquí, el estudio de López Sastre sobre el historiador escocés William Robertson es digno de destacar, así como la discusión de Fermín del Pino Díaz sobre la argumentación de la Historia del Nuevo Mundo de Juan B. Muñoz y la defensa de Juan Pimentel de la ciencia española del siglo XVIII. Algo más lejos nos lleva el fascinante trabajo dedicado a la presencia española en Pacífico del Noroeste. Sus autores sugieren que las interacciones españolas con los indígenas en esa región habrían provocado el orgullo de Las Casas. La visión de conjunto de la Leyenda Negra de este volumen se cierra con el ensayo de Álvarez Junco centrado en el siglo XIX y en el desplazamiento de la crudeza de la imagen de España propia de la Ilustración hacia las impresiones románticas más suaves de autores como Lord Byron, Washington Irving y Théophile Gautier. Se echa en falta, no obstante, un tratamiento adecuado de la "leyenda blanca" pro-española difundida a finales del XIX por Charles Lummis y otros autores estadounidenses tendentes a dar un giro positivo sobre los "pioneros" españoles en América del Norte, Central y del Sur.

Pese a sus esfuerzos por ser exhaustiva, La sombra de la Leyenda Negra genera más preguntas que respuestas. Al final de su estudio preliminar, los editores del vo- 
lumen piden al lector que se desprenda de cualquier prejuicio que pudiera tener sobre la Leyenda Negra y que la acepte como una realidad en oposición a un producto de la imaginación española. Sin embargo, confunden los asuntos exhortándolo a ser "abierto a la verdad (p. 83)", sin llegar a explicar de qué verdad se trata.

Desde mi perspectiva, hay muchas verdades. Cuando, por ejemplo, en 1779 John Adams, quien después sería el segundo presidente de los Estados Unidos, viajó por tierra desde La Coruña a Hondarribia, su comprensión de lo que percibía como atraso y pobreza de la región estaba profundamente teñida por la Ilustración. Como consecuencia, Adams se apresuró a responsabilizar a la Iglesia Católica Romana de la falta de progreso y desarrollo económico. Tal era la "verdad" de la percepción de España de Adams, pero esa percepción no tenía nada en común con la de otro presidente de Estados Unidos, William H. Taft. En un discurso pronunciado en Los Ángeles en 1908 e influido por los escritos de Lummis sobre las glorias de los pioneros españoles, Taft públicamente se refirió a los heroicos logros de España en América y Filipinas.

Como sugiere esta comparación mínima, no hay una manera sencilla de resumir la percepción de los extranjeros sobre España. Tales percepciones varían: cambian con el paso del tiempo; y se contradicen entre sí. Unas son positivas, otras negativas y hasta cierto punto, de la misma forma que la noción de belleza reside en los ojos de quien mira, todas contienen algo de verdad. Lo mismo sucede con la Leyenda Negra y la tarea de los historiadores es ayudar a los lectores -y de forma más amplia, al público en general -a comprender sus orígenes, su evolución, así como la reacción española a esas percepciones. De formas distintas, cada uno de estos volúmenes contribuye de una manera importante, aunque en ocasiones contradictoria, a esta tarea en curso. Pero al fin y a la postre la cuestión antes planteada continúa sin respuesta: ¿por qué la Leyenda Negra? ¿por qué ahora?

Richard L. Kagan

The Johns Hopkins University, Baltimore 